\title{
A Novel Vanadium n-propylamino Phosphate Catalyst: Synthesis, Characterization and Applications
}

\author{
Rajini Anumula, Muralasetti Nookarajua, Kaliaperumal Selvaraj,
} Ingala Ajit Kumar Reddy ${ }^{\mathrm{a}}$ Venkatathri Narayanan ${ }^{\mathrm{a} *}$

\author{
${ }^{a}$ Department of Chemistry, National Institute of Technology, Warangal 506 004, Andhra Pradesh, India \\ ${ }^{\mathrm{b}}$ Catalysis Division, National Chemical Laboratory, Pune 411 008, Maharastra, India
}

Received: January 1, 2012; Revised: September 3, 2012

\begin{abstract}
A novel, lamellar type Vanadium n-propylamino phosphate catalyst is synthesized and characterized by using various physicochemical techniques such as Powder X-ray diffraction, Scanning electron microscopy/Energy dispersive X-ray analysis, Thermogravimetry/Differential thermal analysis, Fourier transform Infrared analysis, Electron spin resonance spectroscopy, Ultraviolet - Visible Diffuse reflectance spectroscopy, $\mathrm{X}$-ray Photoelectron spectroscopy, ${ }^{31} \mathrm{P}$ Magic angle spinning Nuclear Magnetic Resonance spectroscopy and Catalytic applications toward Octahydroquinazolinone synthesis. It is found that the n-propylamine is present as sandwich between Vanadyl phosphate layers. Most of the Vanadium is present as $\mathrm{V}^{4+}$ ions in tetrahedral co-ordination. Vanadium n-propylamino phosphate catalyses Octahydroquinazolinone synthesis more effeciently and the optimum conditions required for Octahydroquinazolinone synthesis are, Benzaldehyde ( $2 \mathrm{mmol})$, Dimedone ( $2 \mathrm{mmol})$, Urea (4 mmol), Methanol + Water (1:1, $5 \mathrm{~mL})$ and Catalyst $(0.05 \mathrm{~g})$. A plausible mechanism is also proposed.
\end{abstract}

Keywords: vanadium, n-propylamino phosphate, octahydroquinazolinones, synthesis

\section{Introduction}

The Octahydroquinazolinones derivatives have attracted considerable attention, as they exhibit potent antibacterial activity against Staphylococcus aureus, Escherichia coli, Pseudomonas aeruginosa ${ }^{1}$, and calcium antagonist activity ${ }^{2,3}$. In 1893, Italian chemist Pietro Biginelli was first reported, the acid catalyzed cyclocondensation reaction of an aldehyde, ethylacetoacetate and urea. This procedure known as Biginelli reaction. Recently, the Biginelli reaction has been found to employ in the synthesis of Octahydroquinazolinones, which involves Knoevenagel condensation, Michael addition and cyclization of aromatic aldehydes, urea and cyclic $\beta$-diketones ${ }^{4}$. Various Lewis acid catalysts such as $\mathrm{Mn}(\mathrm{OAc})_{3}, \mathrm{LiBr}, \mathrm{VCl}_{3}, \mathrm{La}(\mathrm{OTf})_{3}, \mathrm{ZrCl}_{4}$, and $\mathrm{InBr}_{3}$, are employed in the synthesis of dihydropyrimidinones through Biginelli reaction. However the reagents/catalysts are found to be expensive, harmful and are difficult to handle especially in large scale. Literature survey reveals a number of homogeneous and heterogeneous catalytic systems used for synthesis of octahydroquinazolinone derivatives which includes $\mathrm{TMSCl}^{5}$, conc. $\mathrm{H}_{2} \mathrm{SO}_{4}, \mathrm{Nafion}-\mathrm{H}^{6}$, $\mathrm{VOSO}_{4}$, conc. $\mathrm{HCl}$ in ethanol ${ }^{7}$, ammonium metavanadate ${ }^{8}$, ionic liquids ${ }^{9}$ and silica sulfuric acid ${ }^{10}$. However the procedures are having several drawbacks.

Vanadium containing micro porous molecular sieves was found to be active in a number of oxidation reactions. They are industrially important in a number of catalytic processes such as the selective oxidation of hydrocarbons, production of $\mathrm{SO}_{3}$, ammoxidation of hydrocarbons and reduction of nitric oxide ${ }^{11}$. Vanadium phosphates (VPO) are having many applications in

*e-mail: venkatathrin@yahoo.com catalysis, materials science and as heterogeneous catalysts in various organic reactions, because of the nontoxic nature and the ability to promote selective reactions. VPO constitute a interesting class of layered compounds exist in a wide range of structural forms due to the variable valency of Vanadium as well as the large diversity in $\mathrm{VO}_{6}$ octahedron bonding and $\mathrm{PO}_{4}$ structural units. Phases containing Vanadium in $+5,+4$ and +3 oxidation states and co-ordination geometry (tetrahedral, square pyramidal and octahedral) are known. In all the compounds the layers are held together by hydrogen bonding or by weak Vander Waal's interactions and the layered compounds are amenable for intercalation reactions. VPO catalysts are extremely important in heterogeneous catalysis for the selective oxidations of methanol to formaldehyde ${ }^{12}$, benzyl alcohol to benzaldehyde ${ }^{13}$, esterification of oleic acid ${ }^{14}$, Ammoximation of aromatics and alkyl aromatics ${ }^{15}$, n-butane to maleic anhydride ${ }^{16}$, propane to acrylic acid ${ }^{17}$, oxidative dehydrogenation of ethane and propane ${ }^{18}$, epoxidations of allylic alcohols ${ }^{19}$.

The concept of using micelles and long chain surfactants as templates for the synthesis of novel mesoporous silicates was first introduced by a group of scientists at Mobil in $1992^{20}$. From the literature studies, the neutral templating approach using amines as templates leads to the formation of lamellar VPO phases ${ }^{21}$. The role of organic structure directing agents has been discussed ${ }^{22}$ as an important role in the kinetics of nucleation and crystallization. The development of Vanadium containing materials with novel structures and well defined oxidation states of Vanadium is an important area of research in oxidation catalysts. Reports are available regarding the applications of Vanadium as a 
catalyst in organic synthesis such as synthesis of coumarins ${ }^{23}$, 3, 4-dihydropyrimidin-2(1H)-ones, bis-(indolyl) methane's ${ }^{24}$, trimethylsilylation of alcohols ${ }^{25}$, tris (2, 4-dinitrophenoxo) compounds $^{26}$ and mannich-type reactions ${ }^{27}$.

Recently, Venkatathri et al. ${ }^{28}$, reported a novel Manganese organophosphate and Titanium n-propylamino phosphate synthesized using amines as templates. The aim of the present study is to synthesis Vanadium n-propylamino phosphate and characterize it by various physico-chemical techniques such as, powder XRD, SEM/EDAX, TG/DTA, FT-IR, ESR, UV-Vis DRS, XPS and ${ }^{31} \mathrm{P}$ MAS NMR. We are also used the above catalyst for the synthesis of Octahydroquinazolinone derivatives and studied the influence of various synthesis parameters.

\section{Experimental}

\subsection{Materials}

Vanadyl sulphate (98\%, Loba Chemie, India), n-propyl amine (Spectrochem, India), Orthophosphoric acid (85\%, Merck, India), aldehydes (Sisco, India) and dimedone (Oakwood, USA) were used without further purification.

\subsection{Synthesis}

A calculated quantity of 0.01 molar Vanadyl sulphate, was added to 1 molar orthophosphoric acid and stirred mechanically for 5-10 minutes to form a homogeneous mixture. To the well stirred mixture, a 4 molar n-propylamine was added and stirred well to get solid homogeneous Vanadium n-propylamino phosphate. The catalyst was ground well, washed with ether and dried at $40{ }^{\circ} \mathrm{C}$ for 5-10 minutes. The resulting solid was subjected to various physico-chemical characterizations.

The Vanadium n-propylamino phosphate catalyst was analyzed by powder X-ray diffraction using a spectrometer (Philips X'pert Pro PW-3040 model, special detector - X'elerator) supported by small and wide angle goniometers with voltage and current of $40 \mathrm{kV}$ and $30 \mathrm{~mA}$ respectively at room temperature in a $2 \theta$ range of 0 to $50^{\circ}$. The morphology and surface elemental composition of the catalyst were investigated by using scanning electron microscope with EDAX attachment on a JEOL-JSM-5200 electron microscope. The thermal characteristics of the Vanadium n-propylamino phosphate has been studied by Thermo gravimetry/Differential thermal analysis (Diamond TG/DTA thermal analyzer) in a temperature range from 25 to $900{ }^{\circ} \mathrm{C}$ with heating rate of $10{ }^{\circ} \mathrm{C} / \mathrm{min}$ in Nitrogen atmosphere. Fourier transform Infrared spectrum was recorded on a Shimadzu spectrophotometer using $\mathrm{KBr}$ pellet technique. Electron spin resonance spectrum was obtained from Bruker instrument. The co-ordination and oxidation state of Vanadium in Vanadium n-propylamino phosphate was examined by using diffuse reflectance UV-visible spectrometer (Shimadzu UV 2550) with 200 to $800 \mathrm{~nm}$ region and Barium sulphate was used as reference. X-ray photoelectron spectroscopy of Vanadium n-propylamino phosphate was obtained from ESCA-3000. ${ }^{31} \mathrm{P}$ Magic angle spinning nuclear magnetic resonance spectrum were obtained from Bruker MSL-300 instrument.

In a typical reaction, benzaldehyde $(2 \mathrm{mmol})$, dimedone $(2 \mathrm{mmol})$ and urea $(4 \mathrm{mmol})$ were taken in a round bottomed flask. To the above reaction mixture $0.05 \mathrm{~g}$ Vanadium n-propylamino phosphate catalyst was added. The reaction mixture was kept under stirring and reaction progress was monitored by TLC. The solid product was filtered and recrystallized with ethanol. The products were authenticated by melting point, FT-IR and ${ }^{1} \mathrm{H}$ NMR.

\section{Results and Discussions}

The powder X-ray diffraction pattern (Figure 1) of Vanadium n-propylamino phosphate shows peaks at $7.02^{\circ}, 8.7^{\circ}$, $13.1^{\circ}, 13.8^{\circ}, 17.4^{\circ}, 19.0^{\circ}, 21.1^{\circ}, 22.4^{\circ}, 24.3^{\circ}, 25.2^{\circ}, 26.2^{\circ}$ and $32.1^{\circ}, 2 \theta$ values and the corresponding d-spacing's are $12.5 \AA$,

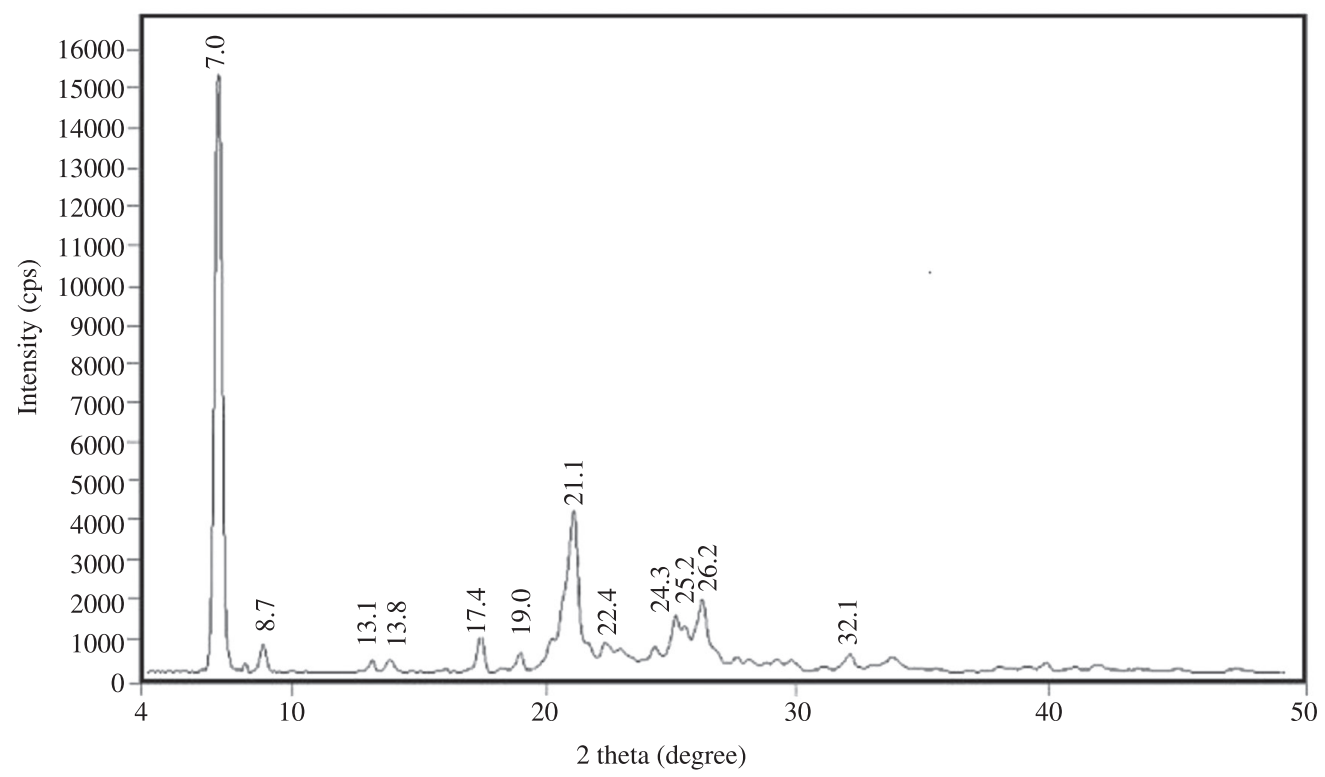

Figure 1. Powder X-ray diffraction pattern of Vanadium n-propylamino phosphate. 
$10.0 \AA$, $6.7 \AA, 6.3 \AA, 5.08 \AA, 4.6 \AA, 4.2 \AA, 3.9 \AA, 3.6 \AA, 3.5 \AA$, $3.3 \AA$, and $2.7 \AA$. The peaks at $21.1^{\circ}$ and $26.2^{\circ}$ values indicates the presence of Vanadium ions ${ }^{29}$ predominantly in $\mathrm{V}^{4+}$ state with small amount in $\mathrm{V}^{5+[30]}$ and peak at $19.0^{\circ}$ indicates the presence of Vanadium phosphate ${ }^{31}$ layer. The peaks at $13.9^{\circ}, 19^{\circ}, 22^{\circ}$, $24^{\circ}$ and $26.2^{\circ}$ are due to the presence of $\mathrm{VOPO}_{4}$ phases $^{32}$ in Vanadium n-propylamino phosphate.

The Scanning electron micrograph (Figure 2) shows homogeneous distribution of the material with plate like structures ${ }^{33}$ and $15-30 \mu \mathrm{m}$ particle size. The Energy dispersive X-ray analysis (Figure 3 ) shows the presence of Vanadium ions on surface.

The Thermogravimetry/Differential thermal analysis (Figure 4) of Vanadium n-propylamino phosphate shows endothermic weight loss at $100-150{ }^{\circ} \mathrm{C}$ are due to



Figure 2. Scanning electron micrograph of Vanadium n-propylamino phosphate. volatilization of physically adsorbed water molecules ${ }^{34}$. The exothermic weight loss at $230-500{ }^{\circ} \mathrm{C}$ is due to the oxidative decomposition of organic molecules ${ }^{35}$.

The Fourier transform Infrared spectrum (Figure 5) of Vanadium n-propylamino phosphate shows a peak at $534 \mathrm{~cm}^{-1}$ associated with the V-O-V rotational vibrations ${ }^{29}$. Peak at $1468 \mathrm{~cm}^{-1}$ is due to the presence of hydrocarbon moiety $\left(-\mathrm{CH}_{2}-\mathrm{CH}_{2}\right)^{36}$. While the peak at $756 \mathrm{~cm}^{-1}$ was due to asymmetric stretching vibrations of $\mathrm{V}-\mathrm{O}-\mathrm{V}$ units ${ }^{37}$. A peak around $1220-1080 \mathrm{~cm}^{-1}$ corresponds to C-N stretching vibration ${ }^{38}$. Peak at $1396 \mathrm{~cm}^{-1}$ may be due to P-O stretching vibration ${ }^{39}$. Peak at $970 \mathrm{~cm}^{-1}$ is due to stretching vibration of $\mathrm{V}=\mathrm{O}$ in the infrared spectrum ${ }^{40}$. The band at $436 \mathrm{~cm}^{-1}$ arises due to $\mathrm{P}-\mathrm{O}$ bending vibrations. Peak at $878 \mathrm{~cm}^{-1}$ may corresponds to condensed P-N units ${ }^{41,42}$. The broad band at $3416 \mathrm{~cm}^{-1}$ may be due to N-H stretching vibrations ${ }^{43}$. Peak in the range of $1650-1590 \mathrm{~cm}^{-1}$ corresponds to $\mathrm{N}-\mathrm{H}$ bending vibrations. The material may possess lamellar type of structure, explained by the profile of the absorption band due to the $\mathrm{VOPO}_{4}$ lattice vibration at $970 \mathrm{~cm}^{-1}$ was retained after the synthesis, suggesting the lamellar nature and intercalation compound was formed involving a V-P-O framework with the organic molecules ${ }^{44}$. The Vanadium phosphate layers may be sandwitched by n-propylamine (Figure 6$)^{45,46}$.

The Electron spin resonance spectrum (Figure 7) of Vanadium n-propylamino phosphate exhibits a typical characteristic eight-line hyperfine patterns originated from the interaction of an unpaired electron with nuclear spin $(I=7 / 2)$ of ${ }^{51} \mathrm{~V}$ (natural abundance 99.8\%). The well-resolved hyperfine patterns further indicate the paramagnetic center $\mathrm{VO}^{2+}$ is well dispersed in the sample. The EPR parameters $(\mathrm{g} l l=1.931, \mathrm{~g} \perp=1.991, A l l=180.5 \mathrm{G}, A \perp=69.5 \mathrm{G})$ corresponds to $\mathrm{V}^{4+}$ in square pyramidal environment ${ }^{47}$.

The UV-Vis diffuse reflectance spectrum (Figure 8) of Vanadium n-propylamino phosphate shows a band at $250 \mathrm{~nm}$ due to $\mathrm{VO}^{2+}$ species present in tetrahedral coordination ${ }^{34}$.



Figure 3. Energy dispersive X-ray analysis of Vanadium n-propylamino phosphate. 
The band at 300-320 $\mathrm{nm}$ is in favour of high dispersion of $\mathrm{V}^{5+}$ ions in the lattice and due to $(\mathrm{V}=\mathrm{O})(\pi) \mathrm{t}_{2} \rightarrow(\mathrm{d}) \mathrm{e}$ and $(\pi) \mathrm{t}_{1} \rightarrow(\mathrm{d}) \mathrm{e}$ electron transfer transitions ${ }^{48}$ resulting from $\mathrm{V}^{5+}$ in tetrahedral environment. Hence, UV-Vis diffuse reflectance spectrum explains $\mathrm{V}^{4+}$ and $\mathrm{V}^{5+}$ ions are co-existed in the catalyst. Presence of a broad peak at $410-460 \mathrm{~nm}$ is due to charge transfer transitions of $\mathrm{V}^{5+}$ species $(\mathrm{V}=\mathrm{O})$ in square pyramidal geometry ${ }^{49}$.

The X-ray photoelectron spectra (Figure 9a, b) of Vanadium n-propylamino phosphate shows the carbon 1s spectrum signal at $288 \mathrm{eV}$ was attributed to carbon bonded to oxygen, Nitrogen and Hydrogen respectively ${ }^{50}$. The oxygen $1 \mathrm{~s}$ spectrum shows signal at $534 \mathrm{eV}$ is associated with the bridging oxygen of $\mathrm{P}-\mathrm{O}-\mathrm{P}$ bonds $\mathrm{s}^{51}$. The binding energies for $\mathrm{V}-\mathrm{O}-\mathrm{V}$ and $\mathrm{V}=\mathrm{O}$ structures have been reported to be closer to 531.6-530.9 and 530.3-529.9 eV, respectively ${ }^{52}$ concludes the presence of V-O-P bonds in Vanadium n-propylamino phosphate. The N 1s signal shows peak around 400-404 eV

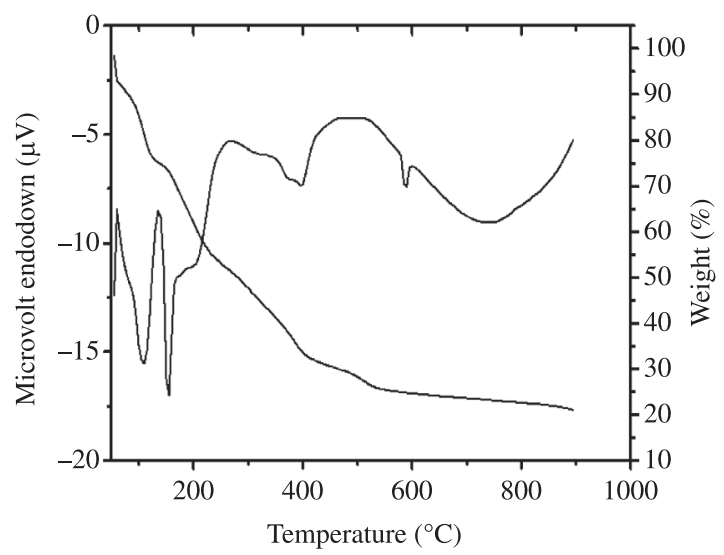

Figure 4. Thermogravimetry/Differential thermal analysis of Vanadium n-propyl amino phosphate. correlated with the photo activity in Visible light ${ }^{53}$ or may be due to presence of interstitial $\mathrm{N}_{2}$ in Vanadium n-propylamino phosphate ${ }^{54}$. The Vanadium ion shows peak at $525 \mathrm{eV}$ corresponding to binding energy of V $2 \mathrm{p}_{1 / 2}$ electron indicates Vanadium exists as $\mathrm{V}^{4+}$ oxidation state and the peak became broadened ${ }^{55}$. The V2p XPS spectrum indicates, Vanadium exists as $\mathrm{V}^{4+}$ and $\mathrm{V}^{5+}$ oxidation states in Vanadium n-propylamino phosphate catalyst. Vanadium n-propylamino phosphate catalyst possesses $\mathrm{V}^{5+}$ species with trace amounts of $\mathrm{V}^{4+}$ species. The $\mathrm{P} 2 \mathrm{p}$ binding energy shows a peak around $137 \mathrm{eV}$ attributed to presence of phosphorous oxide $\mathrm{P}_{2} \mathrm{O}_{5}{ }^{[56]}$ in Vanadium n-propylamino phosphate or related to presence of V-O-P compounds containing mono-, di- and poly- hydrogen phosphate anions ${ }^{57}$.

Phosphorous solid state NMR spectroscopy is a powerful tool to distinguish different valence states of Vanadium surrounding the phosphorous atoms in different environments. ${ }^{31} \mathrm{P}$ MAS NMR spectrum (Figure 10) of Vanadium n-propylamino phosphate shows two ${ }^{31} \mathrm{P}$ peaks, with an intensity ratio of about 1:1 at $0 \mathrm{ppm}$ is ascribed to the presence of phosphorous ${ }^{58}$ in tetrahedral environment ${ }^{59,60}$. According to Bunker et al. ${ }^{60}$ the peaks at $0 \mathrm{ppm}$ is due to presence of $\mathrm{PO}_{2} \mathrm{~N}_{2}$ tetrahedra. The ${ }^{31} \mathrm{P}$ MAS NMR spectrum explains two kinds of tetrahedra are formed simultaneously, at the expense of the $\mathrm{PO}_{4}$ tetrahedral ${ }^{61}$. Phosphorous atoms at $\mathrm{VOPO}_{4}$, in the neighborhood of $\mathrm{V}^{5+}$ species, leads to narrow ${ }^{31} \mathrm{P}$ MAS NMR signals in the range of ca. -22 to $4 \mathrm{ppm}^{62}$.

\section{Catalytic Properties}

\subsection{Influence of substituted aldehydes}

In order to confirm the versatility of the catalyst, the standard reaction was carried out by using various aromatic aldehydes in methanol and water. [Table 1, entries 1 to 7]. In all the cases, the reactions proceed smoothly to afford

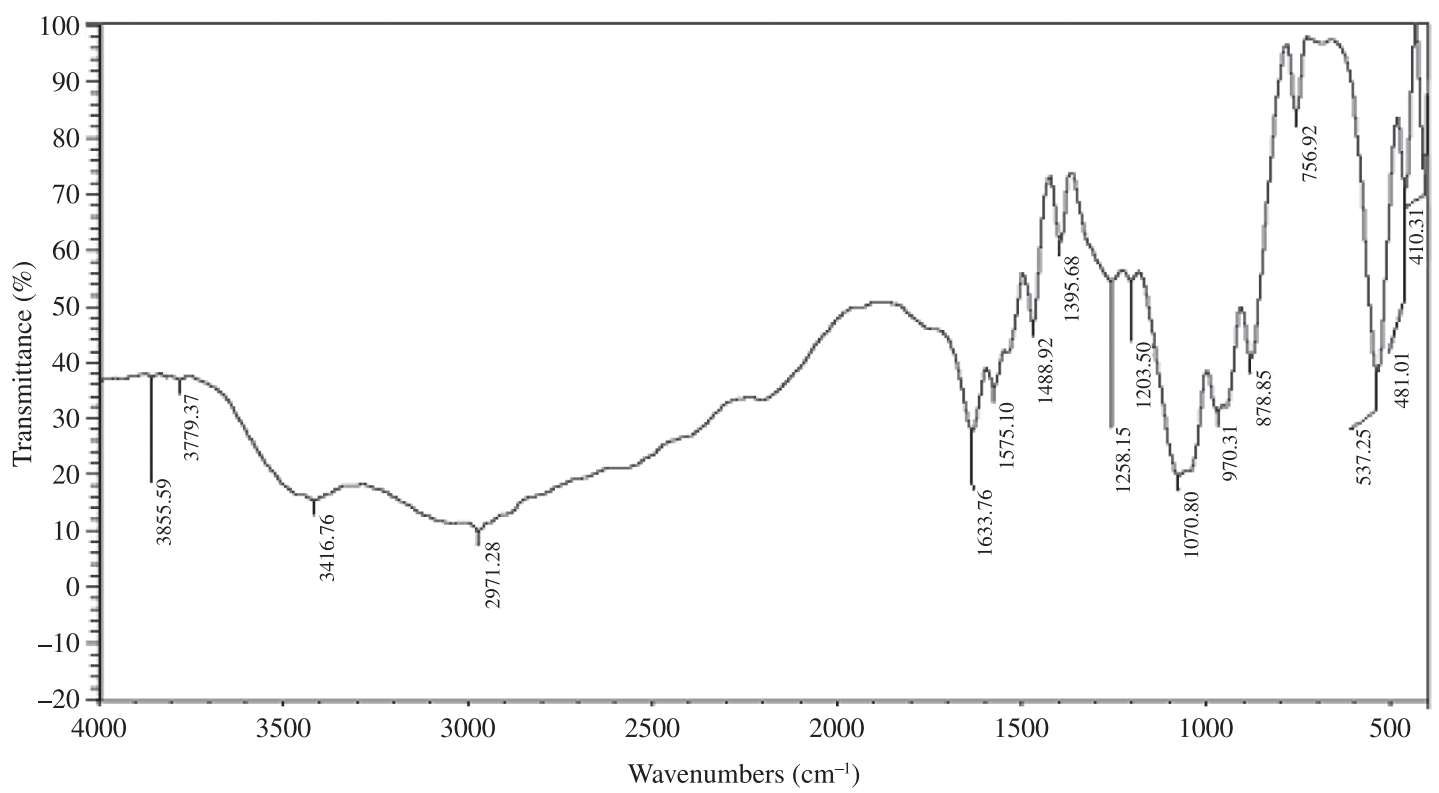

Figure 5. Fourier transform Infrared spectrum of Vanadium n-propylamino phosphate. 


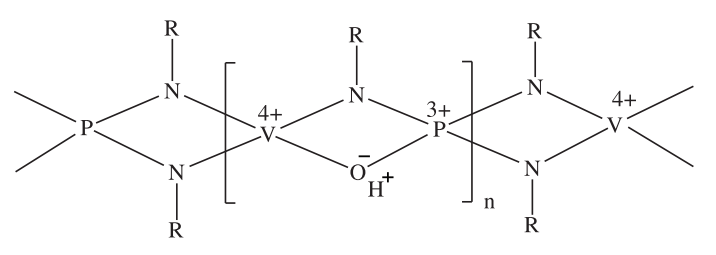

$\mathrm{R}=\mathrm{n}$-propylamine

Figure 6. Structure of Vanadium n-propylamino phosphate catalyst.

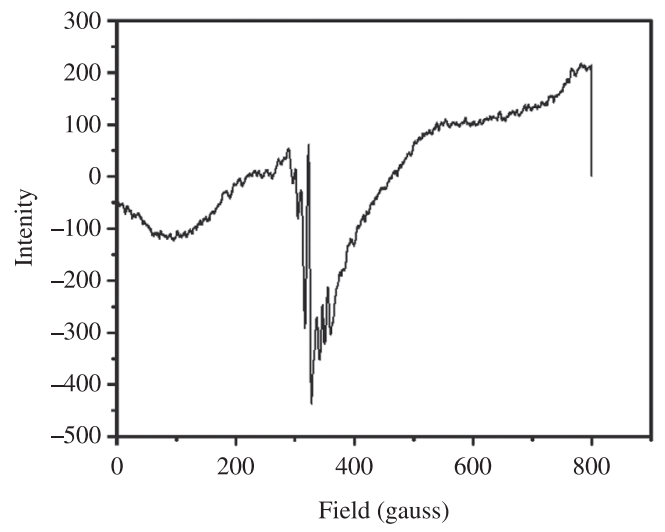

Figure 7. Electron spin resonance spectrum of Vanadium n-propylamino phosphate.



Figure 8. Ultraviolet - Visible diffuse reflectance spectrum of Vanadium n-propylamino phosphate.

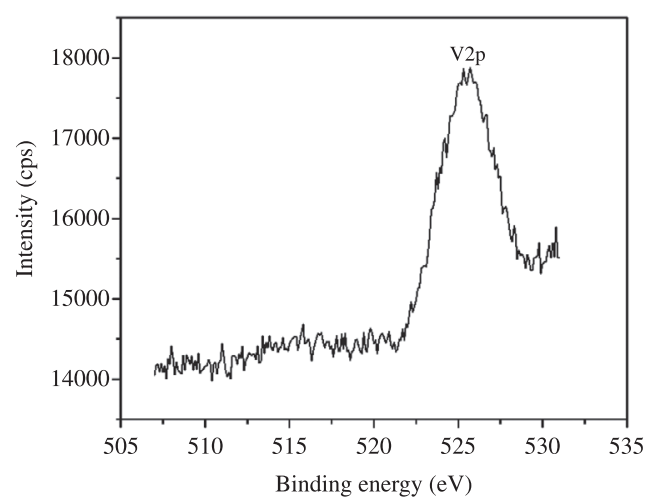

(a) the desired octahydroquinazolinone derivatives in $69-85 \%$ yields. The yields obtained were good to excellent without formation of side products. The aromatic aldehydes bearing electron withdrawing groups $\left(\mathrm{p}-\mathrm{NO}_{2}, \mathrm{p}-\mathrm{Br}\right)$ reacted at faster rate compared with aromatic aldehydes substituted with electron releasing groups (p-methyl, p-hydroxyl. The corresponding products and yields were illustrated in Table 1.

\subsection{Influence of solvents}

Influence of solvents (Table 2) on the synthesis of octahydroquinazolinones is studied in presence of $0.05 \mathrm{~g}$ Vanadium n-propylamino phosphate have been monitored using solvents tetrahydrofuran, chloroform, water, acetonitrile, ethanol, methanol and methanol + water $(1: 1)$ at $60{ }^{\circ} \mathrm{C}$. In comparison with other solvents, combination of methanol, water gave the products with higher yields. As protic solvents, methanol and water will solubilize dimedone and bring the reactants on the surface of the catalyst and enhance the yield. However, the reaction did not proceed in aprotic solvents like acetonitrile, chloroform and tetrahydrofuran.

\subsection{Influence of the amount of catalyst}

In order to optimize the amount of Vanadium n-propylamino phosphate catalyst for the synthesis of octahydroquinazolinone derivatives, the reaction was carried out by varying the amount of catalyst from $0.03 \mathrm{~g}$ to $0.1 \mathrm{~g}$ (Table 3). With increase in amount of Vanadium

Table 1. Synthesis of various octahydroquinazolinones using methanol + water $(1: 1)$ solvent at reflux condition.

\begin{tabular}{ccccc}
\hline S. No. & $\mathbf{R}$ & $\begin{array}{c}\text { Time } \\
(\text { minutes })\end{array}$ & M.P $\left({ }^{\circ} \mathbf{C}\right)$ & Yield (\%) \\
\hline 1 & $\mathrm{H}^{*}$ & 90 & $290-293$ & 30 \\
2 & $\mathrm{H}$ & 90 & $290-293$ & 85 \\
3 & $4-\mathrm{Cl}$ & 120 & $>300$ & 75 \\
4 & $4-\mathrm{BrC}_{6} \mathrm{H}_{4}$ & 90 & $>300$ & 85 \\
5 & $4-\mathrm{MeC}_{6} \mathrm{H}_{4}$ & 120 & $>300$ & 69 \\
6 & $4-\mathrm{NO}_{2} \mathrm{C}_{6} \mathrm{H}_{4}$ & 90 & $304-305$ & 73 \\
7 & $4-\mathrm{OHC}_{6} \mathrm{H}_{4}$ & 180 & $300-302$ & 71 \\
\hline
\end{tabular}

* $\mathrm{VOSO}_{4} .5 \mathrm{H}_{2} \mathrm{O}$ (catalyst); conditions: benzaldehyde $(2 \mathrm{mmol})$; dimedone $(2 \mathrm{mmol})$; urea $(4 \mathrm{mmol})$; methanol + water $(5 \mathrm{~mL}) ; 0.05 \mathrm{~g}$ vanadium n-propylamino phosphate catalyst.

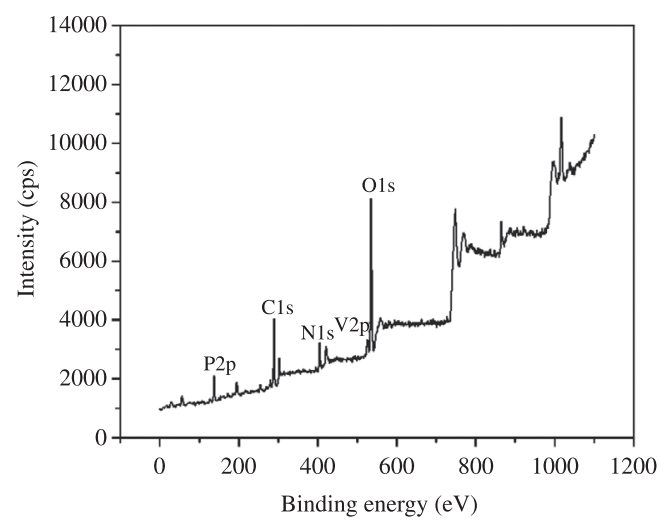

(b)

Figure 9. X-ray photoelectron spectras of Vanadium n-propylamino phosphate. (a) Vanadium ion (b) survey spectrum. 


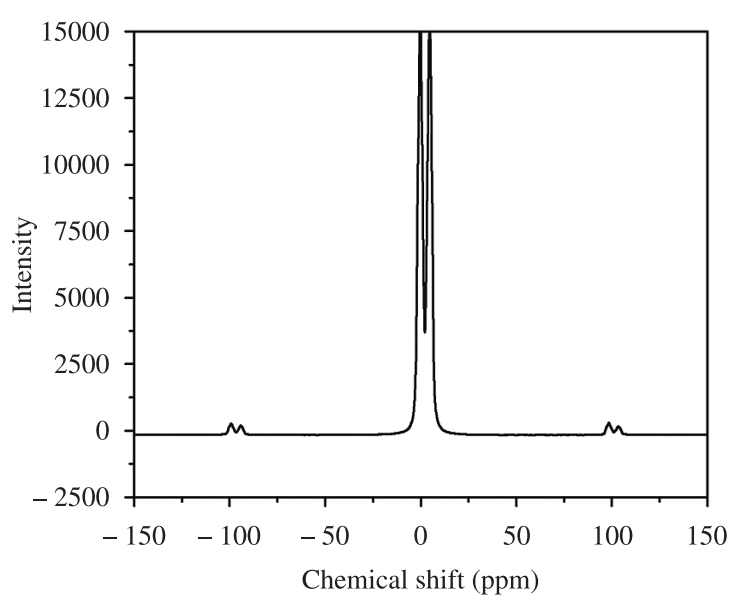

Figure 10. ${ }^{31} \mathrm{P}$ MAS NMR spectrum of Vanadium n-propylamino phosphate. n-propylamino phosphate catalyst from $0.03 \mathrm{~g}$ to $0.1 \mathrm{~g}$, no change in the reaction time was observed. The optimum amount of catalyst was found to be $0.05 \mathrm{~g}$ with respect to product yield and amount of catalyst. The yields of the products obtained were good to excellent without the formation of side products. The reactions carried out in the presence of Vanadium n-propylamino phosphate shows the formation of only octahydroquinazolinone derivatives.

\subsection{Recyclability of the catalyst}

Catalyst was recovered after the reaction by simple filtration, washed with dichloromethane, dried at ambient temperature and used for the next run. Recyclability of the catalyst (Table 4) for the standard reaction conditions at reflux temperature was investigated. The yields of the product obtained in the subsequent cycles are found to be 80,65 and $50 \%$ (Table 4).<smiles>[R]c1ccccc1C1NC(=O)NC2=C1C(=O)CC(C)(C)C2</smiles>

$\mathrm{R}=\mathrm{H}, \mathrm{p}-\mathrm{CH}_{3}, \mathrm{p}-\mathrm{NO}_{2}, \mathrm{p}-\mathrm{Br}, \mathrm{p}-\mathrm{OH}, \mathrm{p}-\mathrm{Cl}$

$\mathrm{VNPRP}=$ Vanadium n-propylamino phosphate.

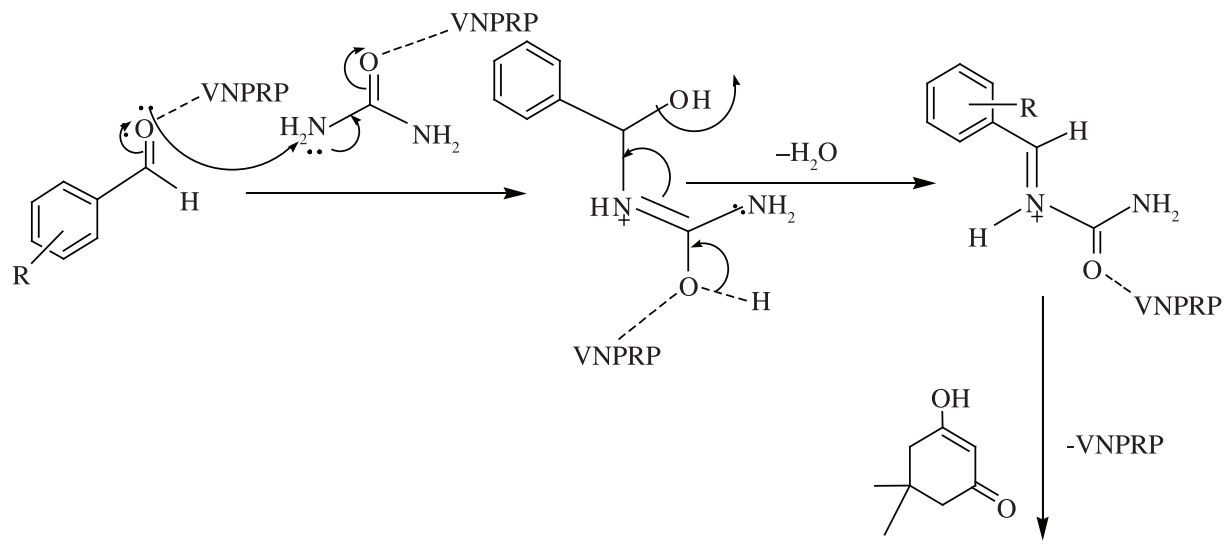

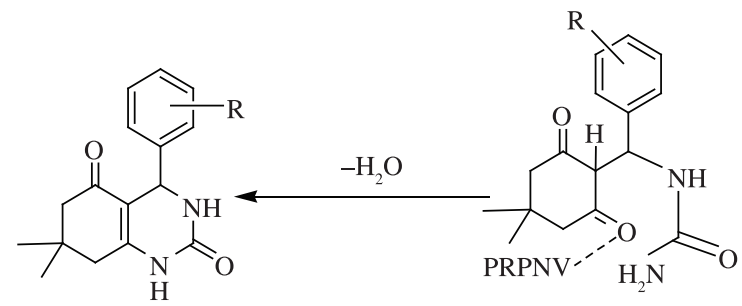

$\mathrm{R}=\mathrm{H}, \mathrm{OH}, \mathrm{CH}_{3}, \mathrm{Cl}, \mathrm{Br}, \mathrm{p}-\mathrm{NO}_{2}$

VNPRP = Vanadium n-propylamino phosphate

Figure 11. Vanadium n-propylamino phosphate catalyst mediated synthesis of various Octahydroquinazolinones. 
Table 2. Influence of various solvents on synthesis of octahydroquinazolinones.

\begin{tabular}{cccc}
\hline S. No. & Solvent & $\begin{array}{c}\text { Time } \\
\text { (minutes) }\end{array}$ & Yield (\%) \\
\hline 1 & Methanol & 90 & 80 \\
2 & Ethanol & 90 & 70 \\
3 & Acetonitrile & 90 & 65 \\
4 & Chloroform & 90 & NR \\
5 & Tetrahydrofuran & 90 & NR \\
6 & Methanol + Water (1:1) & 90 & 85 \\
7 & Water & 90 & NR \\
\hline
\end{tabular}

Conditions: benzaldehyde ( $2 \mathrm{mmol})$; dimedone ( $2 \mathrm{mmol})$; urea (4 mmol); methanol + water $(5 \mathrm{~mL}) ; 0.05 \mathrm{~g}$ vanadium n-propylamino phosphate catalyst; NR - No reaction.

\subsection{Mechanism}

The role of Vanadium n-propylamino phosphate catalyst is to activate the aldehyde by binding the oxygen atom of aldehyde with vacant orbital of Vanadium (Figure 11) to achieve the stable oxidation state. Low acidity and neutrality of Vanadium n-propylamino phosphate catalyst exhibit higher selectivity toward the synthesis of octahydroquinazolinones derivatives.

\section{Conclusions}

A novel Vanadium n-propylamino phosphate catalyst is synthesized and found to have lamellar structure with Vanadyl phosphate layers and n-propylamine sandwich. It was prepared from n-propylamine, Vanadyl sulphate and Orthophosphoric acid. It is characterized in detail by various spectral and physicochemical techniques. The characterization shows that the Vanadium is incorporated
Table 3. Influence of the amount of catalyst on synthesis of octahydroquinazolinones.

\begin{tabular}{cccc}
\hline S. No. & $\begin{array}{c}\text { Amount } \\
(\text { wt. (\%)) }\end{array}$ & Time (minutes) & Yield (\%) \\
\hline 1. & $0.03 \mathrm{~g}$ & 90 & 60 \\
2. & $0.05 \mathrm{~g}$ & 90 & 85 \\
3. & $0.07 \mathrm{~g}$ & 90 & 70 \\
4. & $0.1 \mathrm{~g}$ & 90 & 70 \\
\hline
\end{tabular}

Conditions: benzaldehyde ( $2 \mathrm{mmol})$; dimedone ( $2 \mathrm{mmol})$; urea (4 mmol); methanol + water $(5 \mathrm{~mL})$; Vanadium n-propylamino phosphate catalyst.

Table 4. Reusability of the catalyst.

\begin{tabular}{cccc}
\hline S. No. & $\begin{array}{c}\text { Number of } \\
\text { recycles }\end{array}$ & $\begin{array}{c}\text { Time } \\
\text { (minutes) }\end{array}$ & Yield (\%) \\
\hline 1 & Fresh & 90 & 80 \\
2 & 1 & 150 & 65 \\
3 & 2 & 160 & 40 \\
\hline
\end{tabular}

Conditions: benzaldehyde ( $2 \mathrm{mmol})$; dimedone ( $2 \mathrm{mmol})$; urea (4 mmol); methanol + water $(5 \mathrm{~mL})$; Vanadium n-propylamino phosphate catalyst $(0.05 \mathrm{~g})$.

mainly as $\mathrm{V}^{4+}$ species. The catalytic applications of this material toward octahydroquinazolinones synthesis is established. Influence of various reaction parameters such as different solvents, various amounts of catalyst and aldehydes on Octahydroquinazolinones synthesis have been studied.

\section{Acknowledgements}

The authors are thankful to the Director, National Institute of Technology, Warangal for constant encouragement through out the course of research work and one of the authors, A. R is thankful to the MHRD, Govt of India for a fellowship.

\section{References}

1. Kidwai M, Saxena S, Khan MKR and Thukral SS. Synthesis of 4-aryl-7,7-dimethyl-1,2,3,4,5,6,7,8-octa hydroquinazoline-2-one/thione-5-one derivatives and evaluation as antibacterials. European Journal of Medicinal Chemistry. 2005; 40(8):816-819. PMid:16122583. http:// dx.doi.org/10.1016/j.ejmech.2005.02.009

2. Yarim M, Sarac S, Kilic SF and Erol K. Synthesis and in vitro calcium antagonist activity of 4-aryl-7,7-dimethyl/1,7,7-trimet hyl-1,2,3,4,5,6,7,8-octahydroquinazoline-2,5-dione derivatives. Il Farmaco. 2003; 58(1):17-24. http://dx.doi.org/10.1016/ S0014-827X(02)00009-5

3. Yarim M, Sarac S, Ertan M, Kilic SF and Erol K. Synthesis, enantioseperation and pharmacological activity of 4-aryl-7,7-dimethyl-5-oxo-1,2,3,4,5,6,7,8-octahydroquin azoline-2-thiones. Arzneimittel-Forschung. 2002; 52:27-33.

4. Hassani Z, Islami MR and Kalantari M. An efficient one-pot synthesis of octahydroquinazolinone derivatives using catalytic amount of $\mathrm{H}_{2} \mathrm{SO}_{4}$ in water. Bioorganic \& Medicinal Chemistry Letters. 2006; 16(17):4479-4482. PMid:16806918. http:// dx.doi.org/10.1016/j.bmcl.2006.06.038
5. Kantevari S, Bantu R and Nagarapu L. TMSCl mediated highly efficient one-pot synthesis of octahydroquinazolinone and 1, 8-dioxo-octahydroxanthene derivatives. Arkivoc. 2006; 16:136-148.

6. Lin $\mathrm{H}$, Zhao Q, Xu B and Wang X. Nafion-H catalyzed cyclocondensation reaction for the synthesis of octahydroquinazolinone derivatives. Journal of Molecular Catalysis A: Chemical. 2007; 268(1-2):221-226. http://dx.doi. org/10.1016/j.molcata.2006.12.020

7. Ladani NK, Patel MP and Patel RG. An efficient three component one-pot synthesis of some new octahydroquinazolinone derivatives and investigation of their antimicrobial activities. Arkivoc. 2009; 7:292-302.

8. Niralwad KS, Shingate BB and Shingare MS. Microwave-assisted one-pot synthesis of octahydroquinazolinone derivatives using ammonium metavanadate under solvent-free condition. Tetrahedron Letters. 2010; 51(28):3616-3618. http://dx.doi. org/10.1016/j.tetlet.2010.04.118

9. Niralwad KS, Shingate BB and Shingare MS. Ultrasound-assisted one-pot Synthesis of octahydroquinazolinone derivatives catalyzed by acidic ionic liquid [tbmim $] \mathrm{Cl}_{2} / \mathrm{AlCl}_{3}$. Journal of the Chinese Chemical Society. 2010; 57:89-92. 
10. Mobinikhaledi A, Foroughifar N and Khodaei H. Synthesis of octahydroquinazolinone derivatives using silica sulfuric acid as an efficient catalyst. European Journal of Chemistry. 2010; 1(4):291-293. http://dx.doi.org/10.5155/ eurjchem.1.4.291-293.108

11. Venkatathri N. Synthesis, characterization and catalytic properties of vanadium aluminophosphate molecular sieves VAPO-31 and VAPSO-Amr from non-aqueous media. Applied Catalysis A: General. 2006; 310:31-39. http://dx.doi. org/10.1016/j.apcata.2006.05.001

12. Behera GC and Parida KM. Selective gas phase oxidation of methanol to formaldehyde over aluminum promoted vanadium phosphate. Chemical Engineering Journal. 2012; 180:270-276. http://dx.doi.org/10.1016/j.cej.2011.11.047

13. Behera GC and Parida KM. Liquid phase catalytic oxidation of benzyl alcohol to benzaldehyde over vanadium phosphate catalyst. Applied Catalysis A: General. 2012; 413-414:245-253. http://dx.doi.org/10.1016/j.apcata.2011.11.016

14. Behera GC and Parida KM. Fascinating and challenging role of tungstate promoted vanadium phosphate towards solvent free esterification of oleic acid. Dalton Trans. 2012; 41(4):1325-1331. PMid:22130509. http://dx.doi. org/10.1039/c1dt11318f

15. Cavani F, Foresti E, Trifiro F and Busca G. Nature of active species in the ammoxidation of toluene over $\mathrm{V}_{2} \mathrm{O}_{5} / \mathrm{TiO}_{2}$ catalysts prepared by flash-drying. Journal of Catalysis. 1987; 106(1):251-262. http://dx.doi. org/10.1016/0021-9517(87)90229-6

16. Cavani $\mathrm{F}$ and Trifiro F. Selective oxidation of light alkanes: interaction between the catalyst and the gas phase on different classes of catalytic materials. Catalysis Today. 1999; 51(3-4):561-580. http://dx.doi.org/10.1016/ S0920-5861(99)00041-3

17. Dasgupta S, Agarwal M and Datta A. Mesolamellar vanadium phosphate phases obtained by intercalation of a long chain alkylamine into different catalytically important VPO host lattices. Journal of Molecular Catalysis A: Chemical. 2004; 223(1-2):167-176. http://dx.doi.org/10.1016/j. molcata.2003.09.043

18. Centi G. Some prospects and priorities for future research on vanadyl pyrophosphate. Catalysis Today. 1993; 16(1):147-153. http://dx.doi.org/10.1016/0920-5861(93)85015-R

19. Sharpless KB and Michaelson RC. High stereo- and regioselectivities in the transition metal catalyzed epoxidations of olefinic alcohols by tert-butyl hydroperoxide. Journal of American Chemical Society. 1973; 95(18):6136-6137. http:// dx.doi.org/10.1021/ja00799a061

20. Kresge CT, Leonowicz ME, Roth WJ, Vartuli JC and Beck JS. Ordered mesoporous molecular sieves synthesized by a liquid-crystal template mechanism. Nature. 1992; 359:710-712. http://dx.doi.org/10.1038/359710a0

21. Tanev PT and Pinnavaia TJ. A Neutral Templating Route to Mesoporous Molecular Sieves. Science. 1995; 267(5199):865867. Pmid:17813916. http://dx.doi.org/10.1126/ science.267.5199.865

22. Gabelica Z, Blom N and Derouane EG. Synthesis and characterization of zsm-5 type zeolites: III. A critical evaluation of the role of alkali and ammonium cations. Applied Catalysis. 1983; 5(2):227-242. http://dx.doi.org/10.1016/01669834(83)80135-3

23. Sunil Kumar B, Kumar PS, Srinivasulu N, Rajitha B, Thirupathi Reddy Y, Narsimha Reddy P et al. Vanadium(III) chloride as an effective catalyst for the Pechmann reaction. Chemistry of
Heterocyclic Compounds. 2006; 42(2):172-175. http://dx.doi. org/10.1007/s10593-006-0066-6

24. Shirini F, Yahyazadeh A, Abedini M and Langroodi DI. Vanadium Hydrogen Sulfate Catalyzed Solvent-Free Synthesis of 3,4-Dihydropyrimidin-2(1H)-ones and Bis-(indolyl) methanes. Bulletin Korean Chemical Society. 2010; 31(6):1715-1718. http://dx.doi.org/10.5012/ bkcs.2010.31.6.1715

25. Shirini F, Zolfigol MA, Abedini M and Sakhaei AR. Vanadium Hydrogen Sulfate (I): Chemoselective trimethylsilylation of alcohols and deprotection of trimethylsilyl ethers. Journal Chinese Chemical Society. 2008; 55:943-946. Available from: <http://proj3.sinica.edu.tw/ chem/servxx6/files/ paper_3020_1268463695.pdf>.

26. Sharma N, Sharma R, Kumari M and Chaudhary SC. Synthesis and characterisation of tris(2,4-dinitrophenoxo) monooxovanadium(V) and its complex salts. Turkish Journal of Chemistry. 2011; 35:45-59.

27. Hwang DR and Uang BJ. A Modified Mannich-Type Reaction Catalyzed by VO(acac). ${ }_{2}$. Organic Letters. 2002; 4(3):463-466. PMid:11820905. http://dx.doi.org/10.1021/o1017229j

28. Venkatathri N, Santhanaraj D and Shanthi K. Synthesis, characterization and catalytic properties of a novel $\mathrm{Mn}$ - organophosphate having MFI topology. Bulletin of the Catalysis Society of India. 2008; 7:97-104. Available from: $<$ http://catalysis.chem.iitm.ac.in/articles/731.pdf>.

29. Xue M, Chen H, Zhang H, Auroux A and Shen J. Preparation and characterization of $\mathrm{V}-\mathrm{Ag}-\mathrm{O}$ catalysts for the selective oxidation of toluene. Applied Catalysis A: General. 2010; 379(1-2):7-14. http://dx.doi.org/10.1016/j.apcata.2010.02.023

30. Pillai UR and Sahle-Demessie E. Selective oxidation of alcohols over vanadium phosphorus oxide catalyst using hydrogen peroxide. Applied Catalysis A: General. 2004; 276(1-2):139-144. http://dx.doi.org/10.1016/j. apcata.2004.07.052

31. Xue M, Chen H, Ge J and Shen J. Preparation and characterization of thermally stable high surface area mesoporous vanadium oxides. Microporous and Mesoporous Materials. 2010; 131(1-3):37-44. http://dx.doi.org/10.1016/j. micromeso.2009.11.038

32. Abdelouahab FB, Olier R, Guilhaume N, Lefebvre F and Volta JC. A study by in situ laser Raman spectroscopy of VPO catalysts for n-butane oxidation to maleic anhydride I. Preparation and characterization of pure reference phases. Journal of Catalysis. 1992; 134(1):151-167. http://dx.doi. org/10.1016/0021-9517(92)90218-7

33. Kiely CJ, Burrows A, Sajip S, Hutchings GJ, Sananes MT, Tuel A et al. Characterisation of Variations in Vanadium Phosphate Catalyst Microstructure with Preparation Route. Journal of Catalysis. 1996; 162(1):31-47. http://dx.doi.org/10.1006/ jcat.1996.0257

34. Murgia V, Torres EMF, Gottifredi JC and Sham EL. Sol-gel synthesis of $\mathrm{V}_{2} \mathrm{O}_{5}-\mathrm{SiO}_{2}$ catalyst in the oxidative dehydrogenation of $n$-butane. Applied Catalysis A: General. 2006; 312:134-143. http://dx.doi.org/10.1016/j.apcata.2006.06.042

35. Venkatathri N. Synthesis, characterization and catalytic properties of Nanocrystalline V-MCM-41 molecular sieve from room temperature. Bulletin of the Catalysis Society of India. 2008; 7:129-136.

36. Farias RFD and Airoldi C. Some insights into the reactivity of oxovanadium phosphate: Synthesis and characterization of an $\mathrm{VOPO}_{4}-\mathrm{H}_{2} \mathrm{~N}\left(\mathrm{CH}_{2}\right)_{3} \mathrm{~N}_{\mathrm{H} 2}$ coordination compound. Journal of Serbian Chemical Society. 2005; 70(11):1283-1290. http:// dx.doi.org/10.2298/JSC0511283F 
37. Harreld JH, Dunn B and Nazar LF. Design and synthesis of inorganic-organic hybrid microstructures. International Journal of Inorganic Materials. 1999; 1(2):135-146. http:// dx.doi.org/10.1016/S1466-6049(99)00022-7

38. Ayyappan P, Asnani M, Ramanan A and Piffard Y. Hydrothermal synthesis of a new ethylenediammonium intercalated vanadyl phosphate, $\left(\mathrm{H}_{3} \mathrm{NCH}_{2} \mathrm{CH}_{2} \mathrm{NH}_{3}\right)_{0.5}\left[\mathrm{~V}_{0.32}^{4+} \mathrm{V}_{0.68}^{5+} \mathrm{O}_{2} \mathrm{PO}_{4}\left\{\mathrm{P}(\mathrm{OH})_{2}\right\}_{0.44}\right]$ Proceedings of the Indian Academy of Sciences - Chemical Sciences. 2003; 115(1):33-40.

39. Jiao X, Chen D, Pang W, Xu R and Yue Y. Solvothermal synthesis and characterization of silica-pillared titanium phosphate. Journal of Materials Chemistry. 1998; 8(12):2831-4. http:// dx.doi.org/10.1039/A802838I

40. Shiels RA, Venkatasubbaiah K and Jones CW. Polymer and Silica Supported Tridentate Schiff Base Vanadium Catalysts for the Asymmetric Oxidation of Ethyl Mandelate - Activity, Stability and Recyclability. Advanced Synthesis \& Catalysis. 2008; 350(17):2823-2834. http://dx.doi.org/10.1002/ adsc. 200800486

41. Khainakova SA, Khainakovaa OA, Garcíaa JR, García-Grandaa $\mathrm{S}$ and Blancob JA. Different morphology of organic-inorganic hybrid nanomaterials based on titanium phosphate. Journal of Alloys and Compounds. 2012; 536S: S491-S494. http://dx.doi. org/10.1016/j.jallcom.2011.12.041

42. Janke C, Schneider M, Bentrup U, Radnik J, Martin $\mathrm{A}, \mathrm{Scholz} \mathrm{G}$ et al. Impact of phosphorus and nitrogen on structure and catalytic performance of $\mathrm{VZrPON}$ oxynitrides in the ammoxidation of 3-picoline. Journal of Catalysis. 2011; 277(2):196-207. http://dx.doi.org/10.1016/j. jcat.2010.11.008

43. Shi Z, Zhang D, Li G, Wang L, Lu X, Hua J and Feng S. Hydrothermal synthesis and characterization of layered vanadium phosphite: $\left[\mathrm{HN}\left(\mathrm{C}_{2} \mathrm{H}_{4}\right)_{3} \mathrm{~N}\right]\left[(\mathrm{VO})_{2}\left(\mathrm{HPO}_{3}\right)_{2}(\mathrm{OH})\left(\mathrm{H}_{2} \mathrm{O}\right)\right] \cdot \mathrm{H}_{2} \mathrm{O}$. Journal of Solid State Chemistry. 2003; 172(2):464-470. http:// dx.doi.org/10.1016/S0022-4596(03)00037-9

44. Yamamoto $\mathrm{N}$, Hiyoshi $\mathrm{N}$ and Okuhara T. Thin-Layered Sheets of $\mathrm{VOHPO}_{4} \cdot 0.5 \mathrm{H}_{2} \mathrm{O}$ Prepared from $\mathrm{VOPO}_{4} \cdot 2 \mathrm{H}_{2} \mathrm{O}$ by Intercalation-Exfoliation-Reduction in Alcohol. Chemistry of Materials. 2002; 14(9):3882. http://dx.doi.org/10.1021/ cm020292y

45. Machado MO, Farias RF and Airoldi C. Two different synthetic routes involving the reaction of dodecylamine or nicotinamide with crystalline lamellar vanadylphosphate. Journal of Physics and Chemistry of Solids. 2004; 65(10):1697-1703. http://dx.doi. org/10.1016/j.jpcs.2004.04.008

46. Benziger JB, Guliants V and Sundaresan S. New precursors to vanadium phosphorus oxide catalysts. Catalysis Today. 1997; 33(1-3):49-56. http://dx.doi.org/10.1016/ S0920-5861(96)00135-6

47. Sen T, Rajamohanan PR, Ganapathy S and Sivasanker $\mathrm{S}$. The Nature of Vanadium in Vanado-Silicate (MFI) Molecular Sieves: Influence of Synthesis Methods. Journal of Catalysis. 1996; 163(2):354-364. http://dx.doi.org/10.1006/ jcat.1996.0337

48. Chao KJ, Wu CN, Chang $\mathrm{H}$, Lee LJ and $\mathrm{Hu}$ SF. Incorporation of Vanadium in Mesoporous MCM-41 and Microporous AFI Zeolites. Journal of Physical Chemistry B. 1997; 101(33):6341-6349. http://dx.doi.org/10.1021/ jp970609v

49. Back G, Yu J-S, Lee H and Lee Y-Ill. Synthesis and spectroscopic characterization of vanadium incorporated
V-AlMCM-41 molecular sieves. Journal of the Korean Magnetic Resonance Society. 2006; 10:141-154.

50. Yang J, Bai HZ, Tan XC and Lian JS. IR and XPS investigation of visible-light photocatalysis-Nitrogen-carbon-doped $\mathrm{TiO} 2$ film. Applied Surface Science. 2006; 253(4):1988-1994. http:// dx.doi.org/10.1016/j.apsusc.2006.03.078

51. Khattak GD, Mekki A and Wenger LE. X-ray photoelectron spectroscopy (XPS) and magnetic susceptibility studies of vanadium phosphate glasses. Journal of Non-Crystalline Solids. 2009; 355(43-44):2148-2155. http://dx.doi. org/10.1016/j.jnoncrysol.2009.06.042

52. Tripathi AM, Nair RG and Samdarshi SK. Visible active silver sensitized vanadium titanium mixed metal oxide photocatalyst nanoparticles through sol-gel technique. Solar Energy Materials \& Solar Cells. 2010; 94(12):2379-2385. http:// dx.doi.org/10.1016/j.solmat.2010.08.022

53. Chen XB and Burda C. Photoelectron Spectroscopic Investigation of Nitrogen-Doped Titania Nanoparticles. Journal of Physical Chemistry B. 2004; 108(40):15446-15449. http:// dx.doi.org/10.1021/jp0469160

54. Ananpattarachai J, Kajitvichyanukul P and Seraphin S. Visible light absorption ability and photocatalytic oxidation activity of various interstitial $\mathrm{N}$-doped $\mathrm{TiO}_{2}$ prepared from different nitrogen dopants. Journal of Hazardous Materials 2009; 168:253-261. PMid:19282105. http://dx.doi. org/10.1016/j.jhazmat.2009.02.036

55. Nagaraju P, Lingaiah N, Balaraju A and Prasad PSS Studies on vanadium-doped iron phosphate catalysts for the ammoxidation of methylpyrazine. Applied Catalysis A: General. 2008; 339(2):99-107. http://dx.doi.org/10.1016/j. apcata.2007.09.032

56. Fluck E and Weber D. P 2p binding energies in phosphorus (III) compounds, phosphonium salts and oxiacids of phosphorus. $Z$ Naturforsch 1974; B29:603-607.

57. Chary KVR, Kumar CP, Naresh D, Bhaskar T and Sakata Y. Characterization and reactivity of $\mathrm{Al}_{2} \mathrm{O}_{3}-\mathrm{ZrO}_{2}$ supported vanadium oxide catalysts. Journal of Molecular Catalysis A: Chemical. 2006; 243(2):149-157. http://dx.doi.org/10.1016/j. molcata.2005.07.036

58. Bourbigot S, Le Bras M, Delobel R. Carbonization mechanisms resulting from intumescence-part II. Association with an ethylene terpolymer and the ammonium polyphosphate-pentaerythritol fire retardant system. Carbon. 1995; 33(3):283-94. http:// dx.doi.org/10.1016/0008-6223(94)00131-I

59. Park Y, Kim W, Park H, Tachikawa T, Majima T and Choi W. Carbon-doped $\mathrm{TiO}_{2}$ photocatalyst synthesized without using an external carbon precursor and the visible light activity. Applied Catalysis B: Environmental. 2009; 91(1-2):355-361. http://dx.doi.org/10.1016/j.apcatb.2009.06.001

60. Bunker BC, Tallant DR, Balfe CA, Kirkpatrick RJ, Turner GL and Reidmeyer MR. Structure of Phosphorus Oxynitride Glasses. Journal of the American Ceramic Society. 1987; 70(9):675-681. http://dx.doi.org/10.1111/j.1151-2916.1987.tb05738.x

61. Hutchings GJ, Lopez-Sanchez JA, Bartley JK, Webster JM, Burrows A, Kiely CJ et al. Amorphous Vanadium Phosphate Catalysts Prepared Using Precipitation with Supercritical $\mathrm{CO}_{2}$ as an Antisolvent. Journal of Catalysis. 2002; 208(1):197-210. http://dx.doi.org/10.1006/jcat.2002.3555

62. Sananes MT, Tuel A and Volta JC. A Study by ${ }^{31} \mathrm{P}$ NMR Spin-Echo Mapping of VPO Catalysts: I. Characterization of the Reference Phases. Journal of Catalysis. 1994; 145(2):251-255. http://dx.doi.org/10.1006/jcat.1994.1032 